\title{
Endoscopy in the treatment of slit ventricle syndrome
}

\author{
JIAPING ZHENG, GUOQIANG CHEN, QING XIAO, YIYANG HUANG and YUPENG GUO \\ Department of Neurosurgery, Aviation General Hospital of China Medical University, Beijing 100012, P.R. China
}

Received December 23, 2015; Accepted January 26, 2017

DOI: $10.3892 /$ etm.2017.4973

\begin{abstract}
The present study aimed to investigate the efficacy of endoscopy in the treatment of post-shunt placement for slit ventricle syndrome (SVS). Endoscopic surgery was performed on 18 patients with SVS between October 2004 and December 2012. Sex, age, causes of the hydrocephalus, ventricular size and imaging data were collected and analyzed. All patients were divided into two groups according to ventricular size and underwent endoscopic surgeries, including endoscopic third ventriculostomy (ETV), endoscopic aqueductoplasty and cystocisternostomy. All treated patients were observed postoperatively for a period of 2 to 3 weeks, and outpatient follow-up was subsequently scheduled for $>12$ months. Clinical results, including catheter adherence, shunt removal and complications, were analyzed during the follow-up period. The success rate of endoscopic surgery was indicated to be $82.7 \%$. Syndromes caused by aqueductal stenosis in 15 patients who underwent ETV were relieved; however, syndromes in the 3 patients with cerebral cysticercosis, suprasellar arachnoid cysts, pinea larea glioma and communicating hydrocephalus, respectively, were not relieved and underwent shunt placement again. Brain parenchyma, choroid plexus and ependymal tissue were the predominant causes for catheter obstruction and the obstruction rate was indicated to be $77.8 \%(14 / 18)$. Complications, such as pseudobulbar paralysis, infection and intraventricular hemorrhage arose in 3 patients. The present study indicates that endoscopic treatments are effective and ETV may be considered as a recommended option in the treatment of post-shunt placement SVS in hydrocephalus patients.
\end{abstract}

\section{Introduction}

Slit ventricle syndrome (SVS) is a common chronic complication in hydrocephalus patients with shunts (1). It is characterized by the presence of intermittent headaches, slow refilling of the shunt reservoir and small slit-like ventricles

Correspondence to: $\mathrm{Dr}$ Guoqiang Chen, Department of Neurosurgery, Aviation General Hospital of China Medical University, 3 Beiyuan Road, Beijing 100012, P.R. China

E-mail: guoqchen@mail.tsinghua.edu.cn

Key words: hydrocephalus, ventriculoperitoneal shunt, slit ventricle syndrome, endoscopy on imaging studies (2). Furthermore, it may result in various symptoms associated with intracranial hypertension (nausea, vomiting and chronic migraines) and hypotension (postural headaches) (3). Several risk factors may contribute to the development of SVS, including patient age, the cause of hydrocephalus, ventricular size, revisions of the shunt system and its valve type (4,5). Additionally, SVS, as a severe shunt-induced complication of hydrocephalus, has been increasingly investigated over the past few years.

Various management options have been applied to the treatment of shunt-induced complication, including SVS, in hydrocephalus patients (6). Patient management for SVS is predominantly determined by the patient's symptoms, aberrant intracranial pressure and the functional status of ventriculoperitoneal (VP) shunts (2). Traditional management of SVS, such as subtemporal decompression, is able to improve symptoms; however, the recurrence rate following traditional treatment is high $(7,8)$. Previous studies have indicated that endoscopic surgery is considered a safe and effective treatment in hydrocephalus patients, which effectively decreases shunt-induced complications, including SVS $(9,10)$. Endoscopic third ventriculostomy (ETV), endoscopic aqueductoplasty (EA) and cystocisternostomy (CC) are effective procedures of endoscopic treatment for hydrocephalus (11-14). ETV has been confirmed to normalize abnormally high intracranial pressure and decrease the incidence of post-operative ventricular dilation in the treatment of hydrocephalus in children with posterior fossa tumors (11). A preliminary clinical study also demonstrated that ETV may be performed in the treatment of communicating hydrocephalus (12). Furthermore, EA is recommended in the management of obstructive hydrocephalus caused by aqueductal stenosis (13). CC has been identified to aid in the treatment of suprasellar arachnoid cysts (SACs) in children with neuroendoscopy (14). Despite advances in the treatment of hydrocephalus, to date, treating shunt-induced SVS effectively remains a considerable challenge.

In the present study, endoscopic surgeries (ETV,EA and CC) were performed to treat post-shunt placement SVS. The details of these techniques and results obtained in 18 patients with SVS are reported. The present study aimed to investigate the efficacy of endoscopy in the treatment of post-shunt placement SVS.

\section{Materials and methods}

Patients and clinical data. Between October 2004 and December 2012, 18 patients (age range, 1.5-48 years; average 
age, 25.2 years; males:females, 12:6) who were diagnosed with SVS were subjected to endoscopic treatment at the General Hospital of China Aviation affiliated to the Department of Neurosurgery Center (Beijing, China). A summary of the clinical data of these 18 patients is presented in Table I. Due to the limitation of medical apparatus and instruments, a shortage of valves with adaptable opening pressure in the General Hospital of China Aviation (Beijing, China) meant that for 17 cases, fixed pressure shunts (medium pressure level) were used and for 1 case, adjustable pressure shunts were used. Furthermore, the head-end shuts of 3 patients were placed in the frontal of right ventricle, and the head-end shuts of 17 patients were placed in the occipital horns of right ventricle. All patients provided their informed written consent and this study was approved by the Institutional Review Board and Local Ethics Committee.

Inclusion criteria for the present study were as follows: Following VP shunting, intermittent headache symptoms appeared with or without other symptoms, including nausea, vomiting and unconsciousness; imaging studies indicated that clinical symptoms were associated with ventricular state and clinical symptoms were observed when the ventricle was expanded and not observed in slit-ventricle; and phase-contrast cine magnetic resonance imaging (PC-cine MRI) did indicate aqueductal obstruction.

Exclusion criteria were as follows: Imaging studies revealed the ventricle of patients with hydrocephalus was still slit-like following VP shunting and the patients exhibited no clinical symptoms; when headache symptoms manifested in patients, imaging studies showed the ventricle was slit-like; and PC-cine MRI did not indicate aqueductal obstruction.

Surgical procedure. All patients were divided into two groups according to whether they presented with expanded ventricles or slit-ventricles. Rigid endoscopes (RUDOLF Medical $\mathrm{GmbH}$, Tuttlingen, Germany) and fiber endoscopes (Fujinon, Inc., Saitama, Japan) that were 3.8-mm in diameter were used.

The first group included 10 patients with expanded ventricle and ETV was performed. Patients were placed in the supine position on the operating table, with the head flexed $30^{\circ}$. On the right side of the midline by 3 and $1 \mathrm{~cm}$ prior to the coronal suture, the sheathing canal of the rigid endoscope was inserted into the right side of the frontal lobe. The foramen of Monro was unobstructed in 9 patients and the endoscope was able to easily enter into the ventricular cavity, whereas the foramen of Monro of 1 patient was covered by ependymal hyperplasia and the endoscope entered into the ventricular cavity following expansion, using a balloon catheter, accompanied by fornix contusion (Fig. 1). All patients underwent ETV at the third ventricular floor between the papillae and pituitary funnel. The translucent region of the third ventricular floor was punctured with biopsy forceps and the fistula was subsequently expanded to $5 \mathrm{~mm}$ using a balloon catheter.

The second group included 8 patients with slit-ventricles. The shunt catheters were initially ligated with silk thread at clavicle level and ventricular dilation of patients was subsequently detected via computed tomography examination. Only the width of the third ventricle expanded to $>5 \mathrm{~mm}$ in size, which was regarded as the safe region of the endoscopic surgery (expansion time range, $6 \mathrm{~h}$ to 7 days; average time,
$12 \mathrm{~h}$ ), the fiber endoscope was used for surgery. Among this group, 6 patients underwent ETV and 1 patient was subjected to a VP shunt a week later due to hydrocephalus following resection of the pineal larea glima at the age of 10 and infection of the central nervous system was recurrent for 12 years. MRI indicated the third ventricle of this patient had no normal anatomic structure and two cystic structures existed posterior to the third ventricle and corpora quadrigemina (Fig. 2A). Thus, endoscopic aqueductoplasty (EA) was performed using a fiber endoscope, and the fiber endoscope successfully entered into the midbrain aqueduct and smoothly passed into the fourth ventricle following ventricular mild expansion 7 days post-ligation (Fig. 2B-F). One patient was subjected to cystocisternostomy (CC) in order to treat SACs. Additionally, $\mathrm{CC}$ for the above wall of these cysts was first performed and the endoscope subsequently entered into the cyst. Following this, $\mathrm{CC}$ for the under wall of cysts was performed.

Follow-up evaluation. All treated patients were observed postoperatively in the hospital for a period of 2-3 weeks and outpatient follow-up was subsequently scheduled for $>12$ months. Furthermore, clinical results, such as catheter adherence and shunt removal, were analyzed based on the observations gathered during the surgical procedures. Any complications associated with the surgery and whether any symptoms persisted during the follow-up period were noted.

\section{Results}

Imaging studies for 18 patients with SVS. Imaging studies of 18 patients revealed an alternate state of slit-ventricle and mildly expanded ventricle (Fig. 3). If ventricular dilution led to a significant reduction in ventricle size, shunts would be in tight contact with the ventricular wall (Fig. 4). Among these 18 patients, 8 patients exhibited a slit-ventricle while 10 patients exhibited an expanded ventricle. All patients presented with intermittent headache symptoms accompanied by nausea, vomiting and unconsciousness, 2 patients presented with infection and 2 patients exhibited subdural effusion.

Treatment of 18 patients with SVS. In the present study, 16 patients underwent ETV as treatment. Although ETV was considered to be safer and more stable than EA and $\mathrm{CC}, 1$ patient who was treated with the resection of pineal larea glima was previously subjected to EA as treatment and 1 patient with SACs was subjected to CC treatment, due to the difficulty in performing ETV. In addition, the shunt catheter of 3 patients was entered into the brain parenchyma. The ventricular end of shunt catheters in 11 patients were adherent with tissue (5). Among them, the foramen of the shunt catheters of 5 patients was wrapped in ependymal tissue, the foramen of 4 patients was obstructed by choroid plexus and the foramen of 2 patients was wrapped by both (Fig. 5A and B). Furthermore, the foramen of these 11 patients grew new blood vessels (Fig. 5B-D). In sum, the obstruction rate was $77.8 \%$ $(14 / 18)$. Due to catheter adherence, only the shunt placements of 12 patients were completely removed and the ventricular end of shunt placement was left in situ. Detailed clinical data of 18 patients is SVS was indicated in Table I. 
A
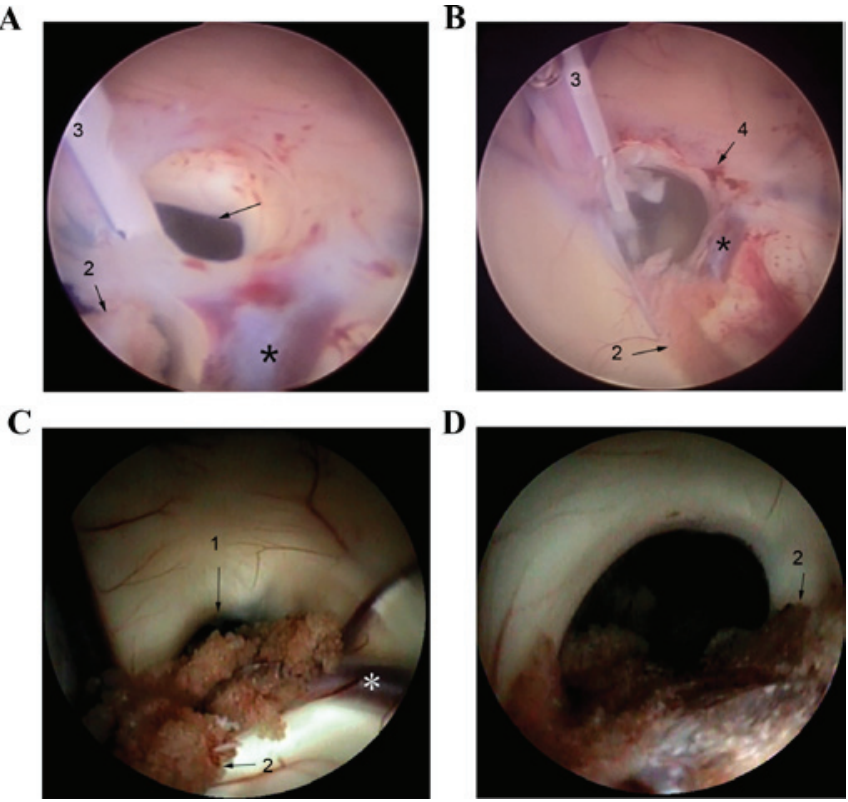

D

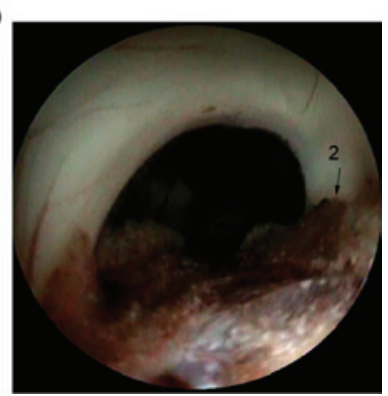

Figure 1. Fornix contusion was caused by endoscopy when the foramen of Monro was very narrow. (A and B) Fornix contusion was caused by the rigid endoscope. ( $\mathrm{C}$ and $\mathrm{D}$ ) Fornix contusion was caused by fiber endoscope. 1, foramen of Monro; 2, choroid plexus; 3 , shunt catheter; 4 , fornix contusion. *Indicates the thalamostriate vein.

Causes of hydrocephalus. The causes of the hydrocephalus in the present study included aqueductal stenosis (12 cases), intraventricular hemorrhage (IVH) of prematurity (2 cases), cerebral cysticercosis (1 case), SACs (1 case), pinea larea glioma (1 case) and communicating hydrocephalus (1 case).

Success rate of endoscopy. The success rate of endoscopic surgery as the primary treatment was $82.7 \%$. The SVS symptoms of 15 patients, such as intermittent headache, nausea, vomiting and unconsciousness, were relieved following endoscopic surgery. The syndromes of 3 patients with cerebral cysticercosis, SACs, pinea larea glioma and communicating hydrocephalus, respectively, were not relieved and endoscopic treatment was performed again.

Complication analysis. Following $6 \mathrm{~h}$ of shunt catheter ligation, 1 patient had symptoms of pseudobulbar paralysis, such as vomiting and unconsciousness. This patient recovered consciousness following ETV; however, the patient had difficulty chewing, swallowing and with speech expression. Furthermore, these symptoms were not completely eliminated after 18 months with no additional treatments. In addition, the ventricular end of the shunt of some patients was left in situ, the body temperature of 1 patient increased and cerebrospinal fluid analysis suggested a bacterial infection. A VP shunt was once again administered and ependymal tissue was incised. The retained shunt was completely removed, the body temperature of this patient returned to normal and the results of subsequent cerebrospinal fluid analysis were normal.

CT analysis indicated that 1 patient exhibited IVH following removal of the shunt as a result of shunt catheter adherence with the choroid plexus; however, the blood clot was absorbed and dissipated 2 weeks later, and no permanent complications were observed.
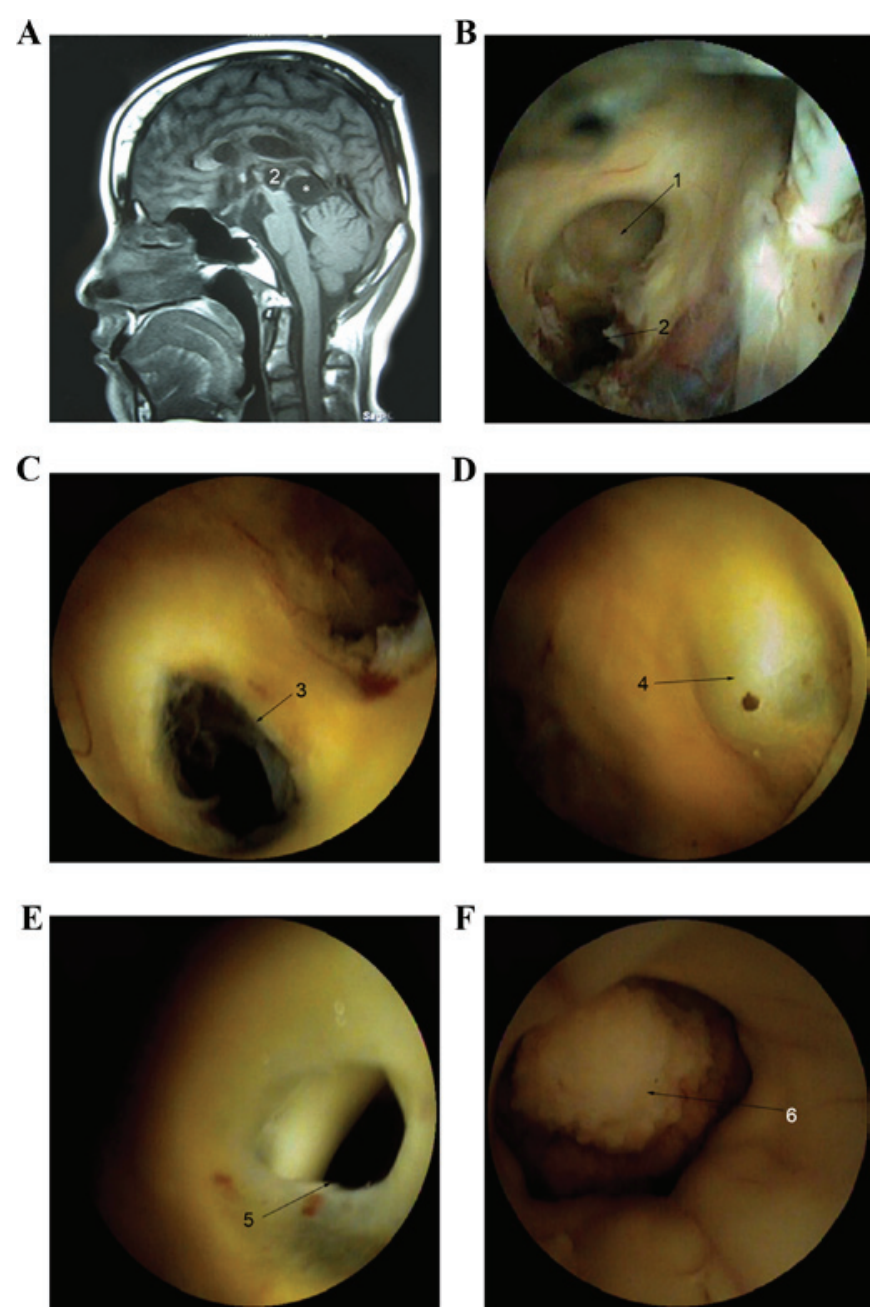

Figure 2. MRI of one patient who was subjected to VP shunting a week later, due to hydrocephalus following the resection of pineal larea glima at the age of 10. Infection of central nervous system was recurrent for 12 years. (A) MRI indicated that the third ventricle of this patient had no normal anatomic structure and two cystic structures existed in the rear of the third ventricle and corpora quadrigemina. (B) Colostomy of the top of cystic structure was performed on the right side of the foramen of Monro. (C-F) Colostomy below the cystic structure was performed and the fiber endoscope entered into the midbrain aqueduct and smoothly into the fourth ventricle following ventricular mild expansion 7 days post-ligation. MRI, magnetic resonance imaging; 1, the foramen of Monro; 2, the cystic structures existed in the rear of the third ventricle; 3 , the fistula between the top and below cyst; 4 , the weak region in the front of cyst; 5 , weak area of fistula; 6 , choroid plexus into the fourth ventricle; "the cystic structures existed in the rear of corpora quadrigemina.

Follow-up analysis. All 18 patients were followed-up for $>12$ months and did not appear to exhibit complications related to endoscopic surgery.

\section{Discussion}

SVS is a common complication in shunt-dependent hydrocephalic patients; however, satisfactory treatment for this condition is still lacking. In the present study, ETV, EA and $\mathrm{CC}$ endoscopic surgeries were performed to investigate the efficacy of endoscopy in the treatment of post-shunt placement SVS. The results indicated that the syndromes of 15 patients were relieved following endoscopic surgery and 3 patients with cerebral cysticercosis, SACs, pinea larea glioma and 
Table I. Summary of the clinical characteristics of 18 patients with slit ventricle syndrome.

\begin{tabular}{|c|c|c|c|c|c|c|c|c|c|}
\hline $\begin{array}{l}\text { Case } \\
\text { no. }\end{array}$ & $\begin{array}{l}\text { Sex/ } \\
\text { age }\end{array}$ & $\begin{array}{l}\text { Hydroce- } \\
\text { phalus cause }\end{array}$ & $\begin{array}{l}\text { Ventricular } \\
\text { size }\end{array}$ & $\begin{array}{l}\text { Ligature } \\
\text { tube }\end{array}$ & Treatment & $\begin{array}{l}\text { Catheter } \\
\text { adherent }\end{array}$ & $\begin{array}{l}\text { Remove } \\
\text { shunt }\end{array}$ & Success & $\begin{array}{l}\text { Compli- } \\
\text { cations }\end{array}$ \\
\hline 1 & $\mathrm{~F} / 21$ & $\begin{array}{l}\text { Communicating } \\
\text { hydrocephalus }\end{array}$ & Slit-like & Y & ETV & $\begin{array}{l}\text { Apendymal } \\
\text { tissue }\end{array}$ & Partial & $\mathrm{N}$ & $\mathrm{N}$ \\
\hline 2 & $\mathrm{~F} / 17$ & $\begin{array}{l}\text { Aqueductal } \\
\text { stenosis }\end{array}$ & Expanded & $\mathrm{N}$ & ETV & $\begin{array}{l}\text { Choroid } \\
\text { plexus }\end{array}$ & Complete & $\mathrm{Y}$ & $\mathrm{N}$ \\
\hline 3 & $\mathrm{M} / 1.5$ & $\begin{array}{l}\text { IVH of } \\
\text { prematurity }\end{array}$ & Expanded & $\mathrm{N}$ & ETV & $\mathrm{N}$ & Complete & $\mathrm{Y}$ & $\mathrm{N}$ \\
\hline 4 & $\mathrm{M} / 12$ & $\begin{array}{l}\text { Aqueductal } \\
\text { stenosis }\end{array}$ & Expanded & $\mathrm{N}$ & ETV & $\begin{array}{l}\text { Choroid } \\
\text { plexus }\end{array}$ & Complete & Y & IVH \\
\hline 5 & $\mathrm{M} / 26$ & $\begin{array}{l}\text { Aqueductal } \\
\text { stenosis }\end{array}$ & Expanded & $\mathrm{N}$ & ETV & $\begin{array}{l}\text { Ependymal } \\
\text { tissue }\end{array}$ & Complete & Y & $\mathrm{N}$ \\
\hline 6 & $\mathrm{M} / 5$ & $\begin{array}{l}\text { IVH } \\
\text { of prematurity }\end{array}$ & Expanded & $\mathrm{N}$ & ETV & $\begin{array}{l}\text { Choroid } \\
\text { plexus }\end{array}$ & Complete & $\mathrm{Y}$ & $\mathrm{N}$ \\
\hline 7 & $\mathrm{M} / 32$ & $\begin{array}{l}\text { Aqueductal } \\
\text { stenosis }\end{array}$ & Slit-like & Y & ETV & $\begin{array}{l}\text { Ependymal } \\
\text { tissue }\end{array}$ & Partial & $\mathrm{Y}$ & $\mathrm{N}$ \\
\hline 8 & $\mathrm{M} / 2$ & $\begin{array}{l}\text { Aqueductal } \\
\text { stenosis }\end{array}$ & Expanded & $\mathrm{N}$ & ETV & $\begin{array}{l}\text { Brain } \\
\text { parenchyma }\end{array}$ & Complete & $\mathrm{Y}$ & $\mathrm{N}$ \\
\hline 9 & $\mathrm{~F} / 21$ & $\begin{array}{l}\text { Pinea } \\
\text { larea glioma }\end{array}$ & Slit-like & $\mathrm{Y}$ & EA & $\begin{array}{l}\text { Ependymal } \\
\text { tissue }\end{array}$ & Complete & Y & Infection \\
\hline 10 & $\mathrm{M} / 36$ & $\begin{array}{l}\text { Aqueductal } \\
\text { stenosis }\end{array}$ & Expanded & $\mathrm{N}$ & ETV & $\begin{array}{l}\text { Choroid } \\
\text { plexus }\end{array}$ & Complete & Y & $\mathrm{N}$ \\
\hline 11 & $\mathrm{M} / 14$ & $\begin{array}{l}\text { Aqueductal } \\
\text { stenosis }\end{array}$ & Expanded & $\mathrm{N}$ & ETV & $\begin{array}{l}\text { Choroid plexus } \\
\text { andependymal }\end{array}$ & Ppartial & $\mathrm{Y}$ & $\mathrm{N}$ \\
\hline 12 & $\mathrm{~F} / 14$ & $\begin{array}{l}\text { Aqueductal } \\
\text { stenosis }\end{array}$ & Slit-like & $\mathrm{Y}$ & ETV & $\mathrm{N}$ & Complete & $\mathrm{Y}$ & $\mathrm{N}$ \\
\hline 13 & $\mathrm{~F} / 41$ & $\begin{array}{l}\text { Aqueductal } \\
\text { stenosis }\end{array}$ & Expanded & $\mathrm{N}$ & ETV & $\mathrm{N}$ & Complete & $\mathrm{Y}$ & $\mathrm{N}$ \\
\hline 14 & $\mathrm{M} / 48$ & $\begin{array}{l}\text { Aqueductal } \\
\text { stenosis }\end{array}$ & Expanded & $\mathrm{N}$ & ETV & $\begin{array}{l}\text { Ependymal } \\
\text { tissue }\end{array}$ & Partial & $\mathrm{Y}$ & $\begin{array}{l}\text { Pseudo- } \\
\text { bulbar }\end{array}$ \\
\hline 15 & $\mathrm{M} / 32$ & $\begin{array}{l}\text { Cerebral } \\
\text { cysticercosis }\end{array}$ & Slit-like & $\mathrm{Y}$ & ETV & $\begin{array}{l}\text { Brain } \\
\text { parenchyma }\end{array}$ & $\mathrm{N}$ & $\mathrm{N}$ & $\mathrm{N}$ \\
\hline 16 & $\mathrm{M} / 36$ & $\begin{array}{l}\text { Aqueductal } \\
\text { stenosis }\end{array}$ & Slit-like & Y & ETV & $\mathrm{N}$ & Complete & $\mathrm{Y}$ & $\mathrm{N}$ \\
\hline 17 & $\mathrm{M} / 52$ & $\begin{array}{l}\text { Aqueductal } \\
\text { stenosis }\end{array}$ & Slit-like & Y & ETV & $\begin{array}{l}\text { Brain } \\
\text { parenchyma }\end{array}$ & Partial & $\mathrm{Y}$ & $\mathrm{N}$ \\
\hline 18 & $\mathrm{~F} / 22$ & $\begin{array}{l}\text { Suprasellar } \\
\text { arachnoid } \\
\text { cysts }\end{array}$ & Slit-like & Y & $\mathrm{CC}$ & $\begin{array}{l}\text { Choroid } \\
\text { plexus and } \\
\text { ependymal }\end{array}$ & $\mathrm{N}$ & $\mathrm{N}$ & $\mathrm{N}$ \\
\hline
\end{tabular}

F, female; M, male; Y, yes; N, no; CC, cystocisternostomy; ETV, endoscopic third ventriculostomy; EA, endoscopic aqueductoplasty; IVH, intraventricular hemorrhage.

communicating hydrocephalus, respectively, were not relieved and were subjected to shunt placement again. Complications, such as pseudobulbar paralysis, infection and IVH appeared in 3 patients, respectively.

Several factors affect VP shunt survival in hydrocephalus patients. Khan et al (15) described that aqueductal stenosis, meningitis and previous cranial surgery were risk factors that predisposed patients to early shunt failure. Furthermore, Drake et al (16) demonstrated that the causes of shunt failure included shunt infection, catheter obstruction, dislocation, valve design and functional failure, including over or under drainage. Previous studies have indicated that proximal catheter obstruction is the most common cause of shunt malfunction (17), and the obstruction rate of the proximal catheter accounts for 10-20\% following surgery (18). A clinical study also observed that $61.7 \%$ of the hydrocephalus patients who were subjected to first-time shunt placements appeared to exhibit shunt failure due to obstruction (19). Additionally, the obstructions that cause shunt failure are predominantly choroid plexus and ependymal tissue $(20,21)$. In the present study, choroid plexus and ependymal tissue were indicated to be the predominant causes of catheter obstruction in the procedure 

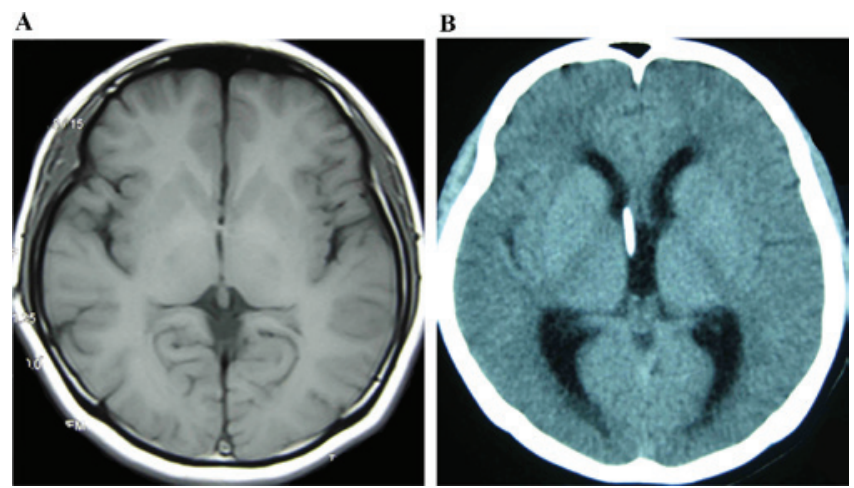

Figure 3. Ventricle images of a female patient with SVS (age 22). (A) Imaging demonstrated an alternate state of slit-ventricle after 6 years with a VP shunt. (B) Imaging indicated an alternate state of ventricle expansion after 8 years with a VP shunt. SVS, slit ventricle syndrome; VP, ventriculoperitoneal.
A

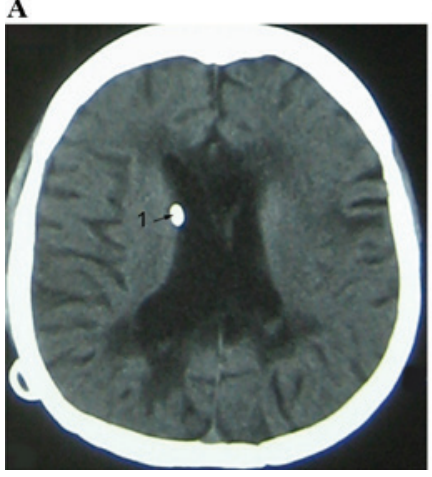

B

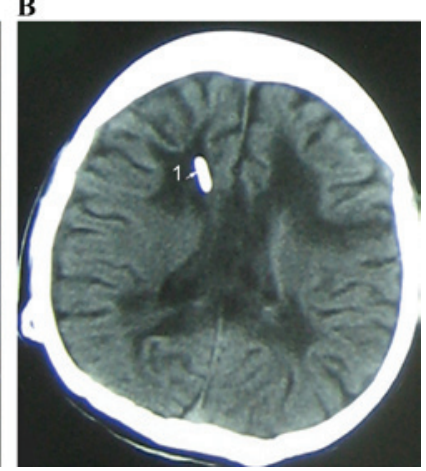

Figure 4. Ventricle images of a female patient with SVS (age 22). (A) Imaging indicated that the ventricle end of the shunt was in close contact with the ventricle wall (arrow). (B) Paraventricular edema was caused by chronic ventricular infection after VP shunting and the ventricle was in slit state (arrow). SVS, slit ventricle syndrome; VP, ventriculoperitoneal.

of endoscopic surgery and the obstruction rate was indicated to be $77.8 \%$ (14/18). Hypersensitive reaction to the silicone material when the shunt came into contact with the ventricular wall, multiple small vessels and activated fibroblasts in the tissue, may be the cause of obstruction to ventricular shunt catheters (21). Furthermore, the present findings indicated that the ventricular end of shunt catheters in 11 patients who underwent ETV were adherent with tissue (Fig. 5). Furthermore, the foramen of these 11 patients grew new blood vessels and contact of the shunt with the ventricular wall was inevitable if ventricular dilation lead to a significant reduction in ventricle size. Therefore, shunt failure and catheter obstruction may be the predominant causes that promote SVS.

Endoscopic treatment has been demonstrated to be effective for obstructive hydrocephalus at the time of shunt malfunction in previously shunted patients (22). ETV is an effective strategy for the management of SVS that occurs following shunt placement (23). Furthermore, an outcome analysis determined that ETV is an effective strategy in the treatment of obstructive hydrocephalus, which is caused by aqueductal stenosis (24). In the present study, 15 SVS patients with hydrocephalus caused by aqueductal stenosis were subjected to ETV, which produced a $100 \%$ success rate. Thus, our results are in line with previous findings and suggest
A

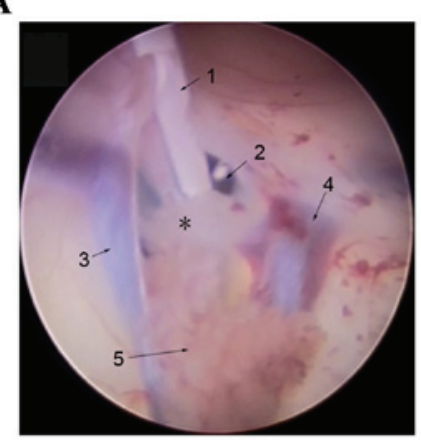

C

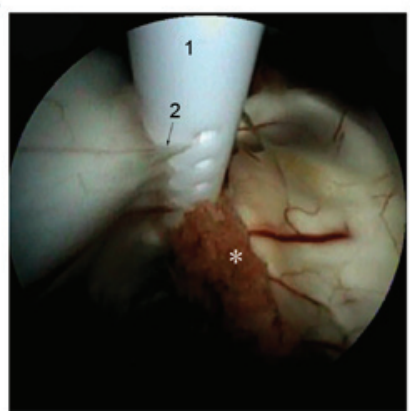

B

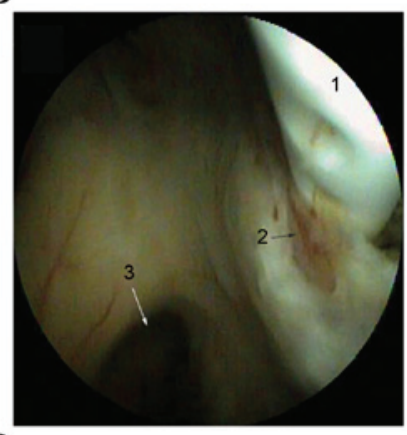

D

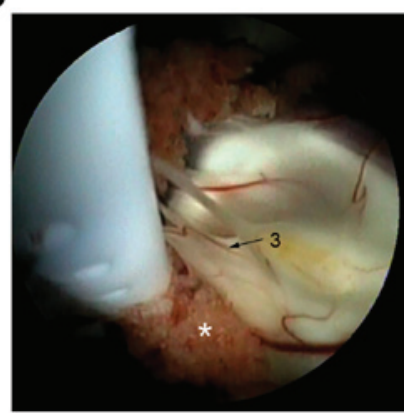

Figure 5. The foramen of the shunt catheter was obstructed. (A) The foramen of the shunt catheter in this patient was covered by ependymal tissue. 1 , the ventricular end of shunt catheter; 2, the foramen of Monro; 3, septum pellucidum vein; 4 , high grain venous; 5 , choroid plexus. (B) The foramen of the shunt catheter of patients was wrapped with ependymal tissue. 1 , the ventricular end of shunt catheter; 2, hyperplasia of the nerves and blood vessels; 3 , the foramen of Monro. (C) Ependymal serrated hyperplasia appeared at the foramen of the shunt catheter. (D) The foramen of the shunt catheter of this patient was obstructed by the choroid plexus. 1 , shunt catheter; 2 , ependymal serrated hyperplasia; 3 , hyperplasia of the nerves and blood vessels; "choroid plexus.

that ETV is a safe and effective strategy for the management of shut-induced SVS. In addition, ETV has a considerable effect on patients with IVH with confirmed CSF dynamic studies (24). Peretta et al (25) also demonstrated that ETV, as a primary treatment for post-hemorrhagic hydrocephalus of prematurity, was effective. Patients with hydrocephalus caused by IVH of prematurity were successfully treated by ETV in the present study. Furthermore a preliminary clinical study identified that ETV may be an effective treatment for communicating hydrocephalus (26). Notably, patient age, the causes of communicating hydrocephalus, and mental state evaluation may be key factors in the outcome prediction of patients who are subjected to ETV (26). In the present study, the symptoms of patients with communicating hydrocephalus were not successfully relieved following ETV. Thus, we speculate that patient age, the causes of communicating hydrocephalus, and mental state evaluation may lead to the failure of ETV. However, further randomized clinical studies are required to validate the efficacy of ETV in communicating hydrocephalus. Clinical outcome analysis revealed that endoscopic treatment is unsafe if the size of the third ventricle is $<5 \mathrm{~mm}$, thus catheter ligation under the collarbone is always performed to expand ventricular size; however, attempting catheter ligation to expand ventricular size has been indicated to be particularly dangerous (24) and may be a limitation of this treatment.

Overcoming shunt complications caused by shunt and endoscopic treatment may be vital for improving the long-term 
outcomes of patients. Some reports suggest that IVH shunt infection and subdural hematoma are related to reduced shunt survival (27-29). Cozzens and Chandler (30) observed an association between IVH and shunt failure. Additionally, a retrospective analysis revealed that shunt infection appears in patients with spinal dysraphism who were subjected to VP shunt placement (31). In the present study low rates of shunt complications and no complications related to the endoscopic operation were exhibited when compared with previous results in the literature, suggesting that endoscopic treatment may be an effective approach for treating SVS caused by shunt-related hydrocephalus.

In conclusion, the present study indicates that endoscopic treatments, particularly ETV, may be effective for the treatment of the patients with SVS. ETV may be considered as a recommended option in the treatment of post-shunt placement SVS in hydrocephalus patients. However, we are uncertain as to whether shunt ligation in a patient with aqueductal stenosis would induce a severe intracranial hemorrhage with complications. Further research, combining shunt ligation with invasive intracranial pressure monitoring, may elucidate a way in which complications may be effectively prevented to some extent.

\section{References}

1. Khorasani L, Sikorski CW and Frim MD: Lumbar CSF shunting preferentially drains the cerebral subarachnoid over the ventricular spaces: Implications for the treatment of slit ventricle syndrome. Pediatr Neurosurg 40: 270-276, 2004.

2. Rekate HL: Classification of slit-ventricle syndromes using intracranial pressure monitoring. Pediatr Neurosurg 19: 15-20, 1993.

3. Bruce DA and Weprin B: The slit ventricle syndrome. Neurosurg Clin N Am 12: 709-717, viii, 2001.

4. Xenos C, Sgouros S, Natarajan K, Walsh AR and Hockley A: Influence of shunt type on ventricular volume changes in children with hydrocephalus. J Neurosurg 98: 277-283, 2003.

5. Walker ML, Fried A and Petronio J: Diagnosis and treatment of the slit ventricle syndrome. Neurosurg Clin N Am 4: 707-714, 1993.

6. Boschert JM and Krauss JK: Endoscopic third ventriculostomy in the treatment of shunt-related over-drainage: Preliminary experience with a new approach how to render ventricles navigable. Clin Neurol Neurosurg 108: 143-149, 2006.

7. Benzel EC, Reeves JD, Kesterson L and Hadden TA: Slit ventricle syndrome in children: Clinical presentation and treatment. Acta Neurochir 117: 7-14, 1992.

8. Allan R and Chaseling R: Subtemporal decompression for slit-ventricle syndrome: Successful outcome after dramatic change in intracranial pressure wave morphology. Report of two cases. J Neurosurg 101 (Suppl 2): S214-S217, 2004.

9. Chernov MF, Kamikawa S, Yamane F, Ishihara S and Hori T: Neurofiberscope-guided management of slit-ventricle syndrome due to shunt placement. J Neurosurg 102 (Suppl 3): S260-S267, 2005.

10. Di Rocco C, Massimi L and Tamburrini G: Shunts vs endoscopic third ventriculostomy in infants: Are there different types and/or rates of complications? A review Childs Nerv Syst 22: 1573-1589, 2006.

11. Ruggiero C, Cinalli G, Spennato P, Aliberti F, Cianciulli E, Trischitta V and Maggi G: Endoscopic third ventriculostomy in the treatment of hydrocephalus in posterior fossa tumors in children. Childs Nerv Syst 20: 828-833, 2004.

12. Singh I, Haris M, Husain M, Husain N, Rastogi M and Gupta RK: Role of endoscopic third ventriculostomy in patients with communicating hydrocephalus: An evaluation by MR ventriculography. Neurosurg Rev 31: 319-325, 2008.
13. da Silva LR, Cavalheiro S and Zymberg ST: Endoscopic aqueductoplasty in the treatment of aqueductal stenosis. Childs Nerv Syst 23: 1263-1268, 2007.

14. Kirollos RW, Javadpour M, May P and Mallucci C: Endoscopic treatment of suprasellar and third ventricle-related arachnoid cysts. Childs Nerv Syst 17: 713-718, 2001.

15. Khan F, Shamim MS, Rehman A and Bari ME: Analysis of factors affecting ventriculoperitoneal shunt survival in pediatric patients. Childs Nerv Syst 29: 791-802, 2013.

16. Drake JM, Kestle JR and Tuli S: Cerebrospinal fluid shunt technology. Clin Neurosurg 47: 336-345, 2000.

17. Dickerman RD, McConathy WJ, Morgan J, Stevens QE, Jolley JT, Schneider S and Mittler MA: Failure rate of frontal versus parietal approaches for proximal catheter placement in ventriculoperitoneal shunts: Revisited. J Clin Neurosci 12: 781-783, 2005.

18. Kestle JR, Drake JM, Cochrane DD, Milner R, Walker ML, Abbott R III and Boop FA; Endoscopic Shunt Insertion Trial participants: Lack of benefit of endoscopic ventriculoperitoneal shunt insertion: A multicenter randomized trial. J Neurosurg 98: 284-290, 2003.

19. Browd SR, Ragel BT, Gottfried ON and Kestle JR: Failure of cerebrospinal fluid shunts: Part I: Obstruction and mechanical failure. Pediatr Neurol 34: 83-92, 2006.

20. Harris CA, Resau JH, Hudson EA, West RA, Moon C, Black AD and McAllister JP II: Reduction of protein adsorption and macrophage and astrocyte adhesion on ventricular catheters by polyethylene glycol and N-acetyl-L-cysteine. J Biomed Mater Res A 98: 425-433, 2011.

21. Takahashi Y, Ohkura A, Hirohata M, Tokutomi $\mathrm{T}$ and Shigemori M: Ultrastructure of obstructive tissue in malfunctioning ventricular catheters without infection. Neurol Med Chir (Tokyo) 38: 399-404, 1998.

22. Hader WJ, Walker RL, Myles ST and Hamilton M: Complications of endoscopic third ventriculostomy in previously shunted patients. Neurosurgery 63 (1 Suppl 1): ONS168-ONS175, 2008.

23. Butler WE and Khan SA: The application of controlled intracranial hypertension in slit ventricle syndrome patients with obstructive hydrocephalus and shunt malfunction. Pediatr Neurosurg 35: 305-310, 2001.

24. Feng H, Huang G, Liao X, Fu K, Tan H, Pu H, Cheng Y, Liu W and Zhao D: Endoscopic third ventriculostomy in the management of obstructive hydrocephalus: An outcome analysis. J Neurosurg 100: 626-633, 2004

25. Peretta P, Ragazzi P, Carlino CF, Gaglini P and Cinalli G: The role of Ommaya reservoir and endoscopic third ventriculostomy in the management of post-hemorrhagic hydrocephalus of prematurity. Childs Nerv Syst 23: 765-771, 2007.

26. Hailong F, Guangfu H, Haibin T, Hong P, Yong C, Weidong L and Dongdong $\mathrm{Z}$ : Endoscopic third ventriculostomy in the management of communicating hydrocephalus: A preliminary study. J Neurosurg 109: 923-930, 2008.

27. Reddy GK, Bollam P, Caldito G, Willis B, Guthikonda B and Nanda A: Ventriculoperitoneal shunt complications in hydrocephalus patients with intracranial tumors: An analysis of relevant risk factors. J Neurooncol 103: 333-342, 2011.

28. Tuli S, Drake J, Lawless J, Wigg M and Lamberti-Pasculli M: Risk factors for repeated cerebrospinal shunt failures in pediatric patients with hydrocephalus. J Neurosurg 92: 31-38, 2000.

29. Rashid QT, Salat MS, Enam K, Kazim SF, Godil SS, Enam SA, Iqbal SP and Azam SI: Time trends and age-related etiologies of pediatric hydrocephalus: Results of a groupwise analysis in a clinical cohort. Childs Nerv Syst 28: 221-227, 2012.

30. Cozzens JW and Chandler JP: Increased risk of distal ventriculoperitoneal shunt obstruction associated with slit valves or distal slits in the peritoneal catheter. J Neurosurg 87: 682-686, 1997.

31. Oktem IS, Menkü A and Ozdemir A: When should ventriculoperitoneal shunt placement be performed in cases with myelomeningocele and hydrocephalus? Turk Neurosurg 18: 387-391, 2008. 